\title{
Current Comments
}

\author{
H. William Axford \\ President, ACRL
}

The recent action of the state of Wisconsin in denying faculty status to librarians in the state system of higher education, and the wiping out of gains which had been made in this direction in the state colleges prior to the merger of the universities and colleges into a single system, should stand as a stark reminder of the difficulties still to be faced in achieving universal acceptance of the idea that academic librarians are entitled to unqualified membership in the faculty club with all rights and privileges pertaining thereunto.

It is probable that many academic librarians will view this latest setback as another example of a malicious conspiracy which stubbornly refuses to view objectively the library's role in higher education and the true nature of the librarian's concomitant responsibilities within it -ergo, the "black ball" at individual institutions and whole state systems such as Wisconsin, Maryland, and California.

Disappointment, frustration, and anger are natural and predictable reactions under the circumstances. These emotions can have positive results if channeled in the right direction and not carried to an extreme. By this I mean that after the first emotional outburst has spent itself, the time for a cold, objective appraisal of what produced the ego jolting action in Wisconsin and elsewhere is at hand.

As galling as it may seem, the fact which no amount of rationalization can obscure is that, when the chips were down, an image other than the one to which we aspire carried the day. Viewed in this light, the tragedy (in the classical Greek sense) of the Wisconsin affair and in every other instance where faculty status has been denied to academic librarians is the rejection of those librarians who, by dint of ego, ambition, and individual effort, did measure up to the standards demanded for admission to the club, but who were denied acceptance by the general image of academic librarians in the minds of the ultimate decision makers and members of the teaching faculty who might otherwise have fought vigorously for admittance. The lesson which emerges with force from Wisconsin is that the burden of proof is on the supplicant, not on those who control the club.

In the struggle for full faculty status for academic librarians, it should be clearly recognized that our worst enemy is the self-limiting attitude of the profession itself, not a conspiracy to deny us the privilege under any and all circumstances. I refer specifically to what might be called the forty-hour week, eleven-month a year syndrome which plays a significant role in preventing the full exploitation of our intellectual capabilities and our potential contribution to higher education, both individually and collectively.

In almost any discussion of faculty status for librarians, the position will be vigorously advanced that, because of our peculiar working conditions, i.e., the forty-hour week and the eleven-month year, in matters related to promotion and tenure, we cannot be measured against the same performance standards as the teaching faculty. It is enough, the argument goes, for a cataloger to be a good cataloger, and a reference librarian a good reference librarian, etc. Any additional requirements such as evidence of intellectual activity related to professional development through research, publication, work with professional organizations, and service to the academic community are totally unrealistic when applied to librarians.

This argument contains a kernel of truth in the sense that the working environment of far too many academic librarians does not provide either positive encouragement or adequate opportunities for professional development. On the other hand, the fact that a great many academic librarians have managed to measure up to the performance standards of the teaching faculty in spite of less than adequate working conditions is a clear indication of the basic weakness of this position. In essence, it reflects on the one hand a reluctance to develop the self-discipline necessary to establish a true professional identity in spite of the obstacles and on the other a willingness to settle for a kind of secure mediocrity. It is this attitude which must be rooted out before we can expect decisions such as the one in Wisconsin to become things of the past.

Crucial to the achievement of general acceptance of full faculty status for academic librarians is the creation of a working environment where the opportunities for professional development are much closer in balance with the responsibilities than is presently the case for the profession as a whole. This goal should be a major thrust of any library faculty development plan.

Here it should be noted that progress in this direction will inherently involve a fairly radical departure from many traditional approaches to library organization and administration for the simple reason that anything approaching a true professional environment cannot exist within 
the traditional Weltanschauung of many academic library administrators, the self-limiting attitudes of many individual librarians as noted above, or the traditional library bureaucracy.

In the spring of 1974 , a library faculty development plan was approved by the university administration at the University of Oregon whose early results seem very promising in terms of stimulating individual effort through the opportunities provided by a more professional working environment. Before presenting a brief description of the program, it should be noted that professional librarians at the University of Oregon have had full faculty status, including professorial titles, since 1930. However, total salary parity, i.e., no member of the library faculty paid less than the minimum salary for his/her rank according to the faculty pay scale, has only been completely achieved within the past two years.

The proposal submitted to the university was quite simple, and its major selling point was probably the fact that no additional funding was required to put the program into operation. It simply asked that the nine-month contract option be opened to library faculty upon request on an ad hoc basis, or as a permanent condition of employment. In all cases, the full twelve-month salary will remain in the library budget and be used to hire recent graduates of professional schools to replace those members of the faculty temporarily on leave. These individuals will be brought into the library as postgraduate fellows. In addition to their professional assignments, they will be required to participate in four seminars involving current issues in academic librarianship along with other members of the library faculty.

Although the nine-month academic contract is an available option, the choice of all those participating in the program to date has been a quarter leave of absence without pay. There are several reasons for this. First of all, there are slight monetary advantages for the individual in going the route of a leave without pay. Secondly, the leave allows the individual to accumulate vacation which can be used to reduce the out-of-pocket costs of a quarter off. Finally, the leave of absence is much simpler to administer because of the differences in appointments and termination dates of fiscal and academic contracts.

The program went into effect on July 1, 1974. To date, there have been five applicants. During summer session 1974, the head of Interlibrary Loan worked as a volunteer in a university library in Göttingen while engaged in an intensive program to master the German language. The head of the Map Collection has requested leave for the spring quarter 1975 to begin editing for publication the manuscripts and field notebooks of several prominent, early Northwest botanists. The head of the Slide Col- lection left on February 1, 1975, for a fourmonth stint as librarian on the Chapman College Floating University of the World. The assistant head of the science library will be spending summer session 1975 working on a biographical directory for a discipline where no such tool now exists. Finally, the Japanese cataloger will be using the spring quarter of 1975 to complete a master's degree in linguistics. Of the five participants to date, three are tenured, two are not.

Whether or not this initial burst of enthusiasm has exhausted the reservoir of pent-up professional energy still remains to be seen. However, this much can be said. The response to the program thus far by the library faculty has sent shivers of approval throughout the university administration. In addition, its implications over the long run have not been lost on some of those members of the university faculty who have not been totally at ease with full faculty status for university librarians, in spite of the fact that this has been a reality at Oregon for over forty years. Nor have they been ignored by the library faculty itself who realize that the Committee on Promotion, Tenure and Achievement will not be very sympathetic to individuals coming up for promotion and tenure who have not taken advantage of the opportunities for professional development which the program offers. No claim is made that the program has or will, in and of itself, bring the responsibilities of full faculty status and the opportunities to meet them closer together. However, it does appear to be a step in the right direction.

\section{Midwinter}

\section{(Continued from page 69)}

ARL/ACRL Task Force on University Library Standards and reaffirms the need to continue the development of standards for university libraries in institutions which grant more than ten doctoral degrees per year."

SUPPORTED the concept of public ownership of the public papers of major government officials, but voted to defer action on a policy statement on the subject, which had been presented by the Rare Books and Manuscripts Section Committee on Manuscripts Collections, in order to consider more extensively the specific language of the statement.

APPROved as a draft for publication in C $b R L$ News the "Statement on the Reproduction of Manuscripts and Archives for Commercial Purposes," prepared by the RBMS Committee on Manuscripts Collections and approved by the Rare Books and Manuscripts Section. [Note: See p. 94 of this issue.]

Approved as policy the "Universal Gift Form 